Вісник ЛНУ імені Тараса Шевченка № 6 (344), Ч. I, 2021

УДК 341.221.4:378(4-11)

DOI: $10.12958 / 2227-2844-2021-6(344)-1-48-63$

\title{
Мигович Ірина Вікторівна,
}

доктор педагогічних наук, доцент, професор кафедри романо-германської філології

факультету іноземних мов Д3 «Луганський національний

університет імені Тараса Шевченка», м. Старобільськ, Україна.

irina.migovich@gmail.com

https://orcid.org/0000-0003-0060-5387

\section{СТАНДАРТИ ЯКОСТІ АКАДЕМІЧНОЇ МОБІЛЬНОСТІ ЯК ЕЛЕМЕНТА СИСТЕМИ ВИЩОЇ ОСВІТИ КІНЦЯ ХХ - ПОЧАТКУ ХХІ СТОЛІТТЯ ТА ЯК ФОРМИ ЇЇ ІНТЕРНАЦІОНАЛІЗАЦІЇ}

Процес інтеграції вищої освіти України до Європейського простору вищої освіти (досліджень), що його було ініційовано кілька десятиліть потому, і нині називають одним із ключових елементів євроінтеграційної політики держави. Цей процес обумовлений низкою чинників, які, спираючись на попередні наші теоретико-методологічні розвідки (Мигович, 2018; 2020), умовно поділяємо на дві групи: 1) зовнішні масовізація та маркетизація вищої освіти; глобалізація національних ринків праці; загальна європейська освітня реструктуризація кінця ХХ століття, яка уможливила формування нормативно-правового підгрунтя інтернаціоналізації європейської вищої освіти; напрацювання міжнародних алгоритмів формування політик та стратегій інтернаціоналізації з метою подальшої їхньої адаптації до національних систем вищої освіти тощо; 2) внутрішні - вплив політичних та економічних чинників на трансформаційні процеси в національних системах вищої освіти окремих країн; законодавче та нормативноправове підгрунтя функціювання окремих форм інтернаціоналізації (мобільність, закордонні стажування, надання освітніх послуг іноземним громадянам тощо) в межах національних систем вищої освіти окремих країн; ресурсне забезпечення процесу інтернаціоналізації у закладах вищої освіти країн (нормативне, фінансове, кадрове, інформаційне) тощо (Мигович, 2020). Супроводжується такий інтеграційний процес і низкою викликів, пов'язаних із забезпеченням якості освітніх послуг, що їх надають національні заклади вищої освіти; забезпеченням інноваційності та привабливості для потенційних студентів (у тому числі і іноземних громадян) національної вищої освіти, що, в свою чергу, сприяє посиленню конкурентоспроможності національних освітніх інституцій тощо. 


\section{Вісник ЛНУ імені Тараса Шевченка № 6 (344), Ч. І, 2021}

Міжнародна академічна мобільність як елемент системи вищої освіти кінця XX - початку XXI століття робить можливим запозичення та поширення позитивного (а в більшості випадків просто іншого) досвіду викладання, навчання, соціальної та громадської активності в освітніх установах іншої країни (Андрущенко, 2010: 34-42); вона покликана сприяти набуттю іiі учасниками низки компетентностей глобалізованого турбулентного світу XXI століття, таких як глобальна, міжкультурна, лінгвістична, підприємницька тощо, а також трансферу кращих практик управління системою вищої освіти до сфери освітнього менеджменту іншої країни. На тлі окреслених перспектив широкого впровадження мобільності в освітній процес не можемо не виділити низку перешкод цьому процесу відносно українських закладів вищої освіти, серед яких «брак фінансування, інертність академічної спільноти, недостатній рівень володіння іноземними мовами, відсутність системи національної мобільності» (Мокій, 2009: 14-17). К. Подольська додає до цього переліку неплановий характер мобільності, нестачу професіоналів у галузі міжнародного навчання / стажування, які працювали би в українських закладах вищої освіти з метою консультування та підтримки, нерозробленість механізмів академічного обміну студентами та викладачами, відсутність у закладах вищої освіти інфраструктури, яка б забезпечувала ефективність академічних обмінів (Подольська, 2010). Враховуючи вищезазначене, для України імплементація та подальша ефективна реалізація міжнародних програм академічної мобільності можливі, зокрема, за умови створення продуктивної системи нормативно-правового забезпечення цього процесу 3 урахуванням європейських та світових стандартів якості академічної мобільності, аналізу яких присвячена ця розвідка.

Національні системи вищої освіти кінця XX - початку XXI століття в умовах глобалізації. Глобалізація справила істотний вплив на функціювання національних систем вищої освіти в усьому світі. Уряди країн світу почали сприймати галузь вищої освіти, сфокусовану на підготовці професіоналів із низкою розвинених компетентностей, необхідних глобалізованому ринку праці XXI століття, як шлях до процвітання своїх країн. Як наслідок, глобалізація викликає масштабну комерціалізацію галузі і, відповідно, необхідність істотного варіювання підходів до процесу надання освітніх послуг та провадження дослідницької діяльності в закладах вищої освіти сьогодення. Глобалізація, на думку Ф. Альтбаха (Ph. Altbach) та Дж. Найт (J. Knight), передбачає залучення економічних, політичних та суспільних сил, які підштовхують вищу освіту XXI століття до більшого міжнародного залучення (... the economic, political, and societal forces pushing $21^{\text {st }}$ century higher education toward greater international involvement) (Альтбах, 2007: 290-291). Вища освіта, яка завжди мала чітко окреслений міжнародний характер, як власне і заклади вищої освіти - університети, що є однією 3 найстаріших соціальних інституцій з тривалою історією 


\section{Вісник ЛНУ імені Тараса Шевченка № 6 (344), Ч. І, 2021}

становлення, здатністю до збереження наявного та формування нового знання i, відповідно, можливістю впливу на розвиток суспільства, у XXI столітті стає все більш інтернаціоналізованою. Американський філософ Р. П. Волфф (R. P. Wolff) відмічає, що спільнота знань відрізняється від будь-якого іншого політичного, релігійного, професійного чи артистичного середовища характером колективних цілей мети та способами їх досягнення. Університет- це особливе суспільство, яке прагне разом зберегти та покращити знання, знайти істину, розкрити та використати інтелектуальні можливості людини; тобто університет - це викладацько-студентська спільнота, яка створює, засвоює, зберігає та передає знання задля служіння людству (зважаємо на відсутність бар'єрів - мобільність - задля реалізації цієї функції) (Торфі, 2008: 44).

Вища, або університетська, освіта - це така форма вищої освіти, яка включає підготовку до самостійного пошуку знань, виконання професійних обов'язків, що вимагають попереднього отримання академічних знань, формування уявлень про відповідні галузі науки та вмінь загалом. Завданням для сучасних університетів $\epsilon$ забезпечення навчання та наукової діяльності, трансферу отриманих від досліджень знань на користь суспільства, формування відчуття соціальної відповідальності, управлінських навичок, надання можливостей для підвищення рівня кваліфікації в майбутньому тощо. Отже, діяльність сучасного європейського та східноєвропейського університету набуває глобального характеру. За словами віцепрезидента німецької ректорської конференції Д. Ленцена (D. Lenzen), тільки насправді транснаціональний університет може виконати місію 3 підготовки громадян світу i проведення досліджень на благо суспільства (Ленцен, 2009). Підсилений розвитком глобальної інформаційної мережі та систем знань процес глобалізації супроводжується зростанням можливостей для кожного суспільства й індивідуума. Оскільки можливості відкриваються тільки для носіїв кваліфікованого знання та сучасних компетентностей, національні системи та заклади вищої освіти стають не тільки об'єктами впливу, але й агентами змін, впливаючи на сприйняття такої традиційної форми трансферу знань, як мобільність студентів, викладачів та адміністративного персоналу університетів, яка й нині залишається наріжним каменем міжнародних академічних відносин та показником ефективності стипендіальних програм, спрямованих на посилення інтелектуального й наукового потенціалу націй засобами фінансової підтримки (Альтбах, 1999).

Академічна мобільність як елемент національних систем вищої освіти кінця XX - початку XXI століття та як форма ї інтернаціоналізації. За останні чотири десятиріччя кількість студентів, які здобувають вищу освіту за межами своєї рідної країни, стрімко зросла з 0,6 мільйона у всьому світі в 1975 році до 2,9 мільйона в 2006 році, а прогнозована кількість іноземних студентів до 2025 року сягатиме 


\section{Вісник ЛНУ імені Тараса Шевченка № 6 (344), Ч. І, 2021}

8 мільйонів осіб по всьому світу. Це стрімке зростання показало, що характер міжнародної академічної мобільності швидко змінювався і набував постійного розвитку 3 точки зору моделей та тенденцій мобільності. По-перше, спостерігаємо зростання попиту на закордонні освітні можливості та наявний потенціал закордонних закладів вищої освіти по всьому світу. По-друге, відмічаємо тенденцію до збільшення та варіювання видів та способів надання освітніх послуг (delivery modes) в приймаючих країнах на додачу до варіювання типів студентів та постачальників освітніх послуг, які задіяні в міжнародному рекрутингу. До прикладу, освітні установи можуть пропонувати освітні програми за межами країн та регіонів свого розташування (транснаціональна освіта), шляхом фізичної присутності в закордонній країні, шляхом дистанційного навчання. Такі процеси зростання попиту та різноманітні моделі реалізації міжнародної освіти супроводжуються посиленою конкуренцією між країнами та між постачальниками освітніх послуг, нестабільністю власне процесу міжнародної мобільності, а отже i непередбачуваністю обсягів потоків студентів за кордон. Стверджуємо, що тривалий час саме академічну мобільність визнавали за пріоритетний напрям інтернаціоналізації національних систем вищої освіти в Свропі, i національні стратегії інтернаціоналізації систем вищої освіти визначали підвищення мобільності студентів та персоналу національних університетів за свою провідну мету. На думку У. Тайхлера (U. Teichler), мобільність як результат процесу міжнародного співробітництва на національному та інституційному рівнях робить можливим взаємозв'язок національного та європейського контекстів, а також більш тісну інтеграцію і зближення різних секторів європейської вищої освіти (Тайхлер, 2009: 93-106).

У контексті Болонських реформ вищої освіти підвищення показників мобільності студентів, викладачів та адміністративного персоналу освітньої установи, транскордонне академічне співробітництво та взаємне визнання періодів навчання і кваліфікацій, здобутих за кордоном, визначені за основну мету Болонського процесу. Увага країн Європейського Союзу зосереджена на підвищенні якості освітніх послуг, що їх надають національні заклади вищої освіти, та дослідницької діяльності, на актуальності вищої освіти та відповідності сформованих у випускників університетів компетентностей потребам глобалізованого ринку праці i, як наслідок, на збільшенні показників працевлаштування молоді в умовах взаємозалежності знання / навичок, економіки і суспільства. Положення Болонської декларації щодо того, що студенти закладів вищої освіти Європейського Союзу мають право на навчання для здобуття ступенів, що визнаються по всій території Союзу, а не тільки в тій країні, де їх здобуто, а також щодо того, що основною відповідальністю національних освітніх установ є гарантування надання однаково високого рівня кваліфікації своїм студентам, $є$ концептуальними щодо мобільності (Гуляєва, 2005: 76-81). Отже, 


\section{Вісник ЛНУ імені Тараса Шевченка № 6 (344), Ч. I, 2021}

Європейський простір вищої освіти (досліджень), з одного боку, сприяє зростанню мобільності студентів та персоналу, а з другого, - мобільність $\epsilon$ необхідною умовою формування та функціювання цього простору.

Інструменти забезпечення сумісності національних складників вищої освіти задля гарантування процесу мобільності розроблено в таких базових документах Болонського процесу, як: Рамка кваліфікацій Європейського простору вищої освіти (The framework of qualifications for the European Higher Education Area); Свропейська рамка кваліфікацій для навчання впродовж життя (The European Qualifications Framework for lifelong learning); Всеосяжна рамка кваліфікацій для Європейського простору вищої освіти (The Overaching Framework for Qualifications in the European Higher Education Area); національні документи щодо національних рамок кваліфікацій, ухвалені на Лондонській конференції міністрів, відповідальних за вищу освіту (2007); Критерії і процедури узгодження національних рівнів кваліфікацій з Європейською рамкою кваліфікації (Додаток до листа Європарламенту і Ради Європи від 06.04.2008 року № 14499); Стандарти і рекомендації щодо забезпечення якості в Свропейському просторі вищої освіти (Standards and Guidelines for Quality Assurancein the European Higher Education Area); Керівництво користувача ECTS (European credit transfer and accumulation System users guide); Хартія європейських університетів для освіти впродовж життя тощо (Болонський процес, 2003; Журавський, 2003; Мигович, 2017; The Bologna Process, 2020). Ці та похідні від них документи роблять можливою так звану «м'яку» кооперацію між європейськими закладами вищої освіти, засновану на обміні студентами та викладачами як базі для реалізації ідеї значущості людських ресурсів для підвищення конкурентоспроможності національних економік (на основі програми ERASMUS, затвердженої в 1987 році).

Майже всі форми інтернаціоналізації національного рівня (програми двостороннього та багатостороннього обміну; інтернаціоналізація навчальних планів; програми професійного розвитку для професорсько-викладацького складу; міжнародне співробітництво на інституційному рівні; міжнародна акредитація освітніх програм; інтеграція дослідницької інфраструктури національних закладів вищої освіти в міжнародні дослідницькі мережі та залучення національних дослідницьких груп до міжнародних проєктів, що фінансуються за допомогою зокрема HORIZON 2020; створення стратегічних альянсів 3 іноземними освітніми установами тощо), є базою для мобільності як компонента національної політики інтернаціоналізації систем вищої освіти країн, яку розглядаємо у двох площинах - мобільність студентів та мобільність викладачів/персоналу.

Мобільність студентів традиційно вимірюємо за допомогою двох статистичних показників: вхідна та вихідна мобільність. Вхідна мобільність визначається відсотком іноземних студентів, які приїжджають у країну, яка приймає, 3 метою навчання або 


\section{Вісник ЛНУ імені Тараса Шевченка № 6 (344), Ч. І, 2021}

стажування / здійснення дослідницької діяльності. Вихідну мобільність визначаємо відсотком національних студентів, які їдуть навчатися за кордон. Зауважимо, що високий індекс вхідної мобільності зазвичай зумовлений привабливістю національних закладів вищої освіти країн 3 погляду надання освітніх послуг, якості таких послуг; водночас індекс вихідної мобільності зазвичай залежить від заохочення студентів пройти хоча б частину навчання або провести дослідження в закордонній країні, від низької якості освітніх послуг у рідній країні або труднощів, з якими стикаються випускники національних закладів вищої освіти на глобальному та локальному ринках праці внаслідок несформованих компетентностей (Мигович, 2020).

Мобільність викладачів/персоналу також є важливим аспектом інтернаціоналізації національних систем вищої освіти, що здатен впливати на соціально-культурні й наукові зв'язки між країнами, урядами, профільними міністерствами, закладами вищої освіти тощо, так само, як і на реформування глобального та локального ринків праці (Ейміт, 2010: 6-18). Мобільність викладачів/персоналу передбачає стажування i творчі відпустки, участь у програмах професійного розвитку за кордоном, гранти та стипендії на проведення досліджень, штатне коротко- або довгострокове працевлаштування.

Інструментами реалізації мобільності студентів та викладачів/персоналу на національному рівні називаємо національні стипендіальні програми та спеціальні програми, фінансовані міжнародними організаціями в галузі вищої освіти. Так, серед програм мобільності, фінансованих міжнародними організаціями, назвемо Рамкову програму Свропейського Союзу 3 досліджень та інновацій HORIZON 2020, асоційованим членом якої Україна є з 2015 року. Станом на 2019 рік за підсумками 446 конкурсів для 117 українських організаційучасників програми передбачено фінансування в сумі 17,232 мільйонів євро (90 проєктів, дев'ять 3 яких координуються українськими установами). Загальна вартість проєктів, у яких станом на кінець 2019 року брали участь 117 українських організацій, - 465,851.011 євро (Міністерство освіти i науки, 2021). Нормативно-правовим забезпеченням процесу інтернаціоналізації на національному рівні в Україні називаємо Положення про начіональний контактний пункт Рамкової програми СC з досліджень та інноваџій HORIZON 2020 (затверджене Наказом Міністерства освіти і науки України № 1469 від 08.12.2016 року), Дорожню карту інтеграчії України до Європейського дослідницького простору (ERA-UA), затвердження якої забезпечить виконання статті 375 Угоди про асоиіацію між Україною та Європейським Союзом i, відповідно, сприятиме формуванню позитивного іміджу країни в європейському просторі освіти та досліджень, посилить науковий потенціал країни для вирішення національних і глобальних викликів, створивши критичну масу вчених у 


\section{Вісник ЛНУ імені Тараса Шевченка № 6 (344), Ч. I, 2021}

багатьох сферах науки та технологій, а також сприятиме ефективному трансферу знань між державними та приватними структурами.

Проте HORIZON 2020 не $\epsilon$ єдиною програмою сприяння мобільності за фінансової підтримки міжнародних організацій. Серед великої кількості інших програм назвемо, зокрема, програму ERASMUS+; програми за підтримки ČRA Support of the development of higher education, Support with reforms and enhancement of capacities in the field higher education; програми за підтримки USAID; програми за підтримки Британської Ради (British Council); програми за підтримки Гете-Інституту (Goethe-Institute); програми від волонтерів Корпусу Миру CША (US Piece Corps); програми підтримки розвитку вищої освіти від посольств країн світу (до прикладу, Academic Exchange Program (US Embassy), English Language Specialist Program, Fulbright Program (US Department of State), Academic mobility programs (Hungary, Slovak Republic, Poland, Czech Republic, Germany, France Embassies), Strengthening Academic Integrity in Ukrainian Higher Education Program (US Embassy) тощо.

Стандарти якості академічної мобільності. Сучасний етап розвитку транскордонної освіти, з одного боку, та інтеграційні процеси національних систем вищої освіти у напрямку Свропейського простору вищої освіти (досліджень), з іншого, ставлять акцент на активному запровадженні системи менеджменту якості (QMS - Quality Management System) до всіх складників функціювання сучасного закладу вищої освіти. Сьогодні існує низка підходів, що дозволяють визначити стандарти оцінки якості міжнародної мобільності. Серед них: 1) стандарт ISO для освітнього сектору - IWA: ISO/IWA 2: Quality Management Systems - Guidelines for the application of ISO 9001:2000 in education; 2) стандарти Міжнародної групи якості Ради акредитації вищої освіти (Council for Higher Education Accreditation's International Quality Group $C I Q G)$; 3) стандарти і рекомендації щодо забезпечення якості в Свропейському просторі вищої освіти (Standards and Guidelines for Quality Assurance in the European Higher Education Area - ESG) (Шеренговський, 2015).

Окрім названих програмних документів питання якості в сфері академічної мобільності висвітлювалися в Стратегії мобільності - 2020 Свропейського простору вищої освіти на конференції в м. Бухарест у 2012 р. Так, прозорість структур й інструментів та взаємна довіра в сфері вищої освіти всіх країн європейського простору обгрунтовується як необхідна передумова для забезпечення мобільності (Mobility for Better Learning, 2012: 4). Показовим в цьому контексті є використання на загальноєвропейському рівні Паспорта мобільності (Europass Mobility) стандартизованого європейського документа, який містить детальні записи про період часу, який людина будь-якого віку, освітнього рівня та професійного статусу витратила в освітніх цілях в інших європейських країнах (документ дозволяє систематизувати та фіксувати досвід 


\section{Вісник ЛНУ імені Тараса Шевченка № 6 (344), Ч. І, 2021}

міжнародного навчання) (Паспорт мобільності, 2015). Записи в Europass Mobility відображають зміст і результати професійної перепідготовки в термінах компетентностей та навичок, достатніх для здійснення цього виду професійної діяльності, або зміст і результати в термінах академічних досягнень (після завершення освітньої програми).

Для забезпечення виконання зазначених вище стандартів поряд із організаційно-правовою підтримкою, наявною на загальнодержавному рівні, визначальною $є$ інституційна політика національних закладів вищої освіти щодо підтримки процесу академічної мобільності в його стандартизованому відповідно до перелічених вище документів модусі. Так, завдяки участі консорціуму українських та закордонних університетів в півторарічному проєкті «Управління інтернаціоналізацією українських закладів вищої освіти в рамках німецько-українського академічного співробітництва 2020 - 2021 років» (Management of Internationalisation and German-Ukrainian Academic Cooperation 2020 - 2021), який реалізують Німецько-українське академічне товариство та Німецька спілка менеджерів наукової сфери у партнерстві з Університетом Лейбніца в межах програми Німецької служби академічних обмінів (Deutscher Akademischer Austauschdienst $D A A D)$ за підтримки Міністерства освіти та науки України, було розроблено низку критеріїв забезпечення якості міжнародної академічної мобільності в рамках процесу інтернаціоналізації як комплексу регулярних заходів, які можуть бути використані українськими університетами і які гарантують, що цільове призначення цих заходів та їх результат відповідають запланованим цілям (Табл. 1).

Таблиия 1.

Комплекс із забезпечення якості міжнародної академічної мобільності в рамках процесу інтернаціоналізації

\begin{tabular}{|c|c|}
\hline Стратегічне завдання & Індикатори реалізації \\
\hline $\begin{array}{c}\text { ЗАВДАННЯ І. } \\
\text { Гармонізація роботи } \\
\text { структурних підрозділів } \\
\text { закладу вищої освіти в } \\
\text { контексті міжнародної } \\
\text { діяльності }\end{array}$ & $\begin{array}{l}\text { 1.1. Гармонізована структура управління міжнародною } \\
\text { діяльністю } 3 \text { нормативним регулюванням основних } \\
\text { напрямів міжнародного співробітництва. } \\
\text { 1.2. Запроваджена інституційна система вдосконалення } \\
\text { мовної та міжкультурної компетентностей співробітників } \\
\text { закладу вищої освіти. }\end{array}$ \\
\hline $\begin{array}{c}\text { ЗАВДАННЯ II. } \\
\text { Системний розвиток } \\
\text { інституційних } \\
\text { стратегічних партнерств }\end{array}$ & $\begin{array}{l}\text { 2.1. Визначене коло стратегічних партнерів закладу вищої } \\
\text { освіти (міжнародні організації, підприємства, установи } \\
\text { різних видів та форм власності; закордонні заклади } \\
\text { вищої освіти (державні та приватні); закордонні наукові / } \\
\text { культурні / спортивні установи) з відповідними } \\
\text { програмами спільних заходів. } \\
\text { 2.2. Розширене коло стратегічних партнерів закладу вищої } \\
\text { освіти (міжнародні організації різних видів та форм } \\
\text { власності; закордонні заклади вищої освіти (державні та } \\
\text { приватні); закордонні наукові / культурні / спортивні } \\
\text { установи). }\end{array}$ \\
\hline $\begin{array}{l}\text { ЗАВДАННЯ III. } \\
\text { Сприяння }\end{array}$ & $\begin{array}{l}\text { 3.1. Сприяння в запровадженні англомовних освітніх } \\
\text { програм; цільових програм мобільності; наявність іноземних }\end{array}$ \\
\hline
\end{tabular}




\section{Вісник ЛНУ імені Тараса Шевченка № 6 (344), Ч. I, 2021}

\begin{tabular}{|c|c|}
\hline $\begin{array}{c}\text { удосконаленню освітніх } \\
\text { програм за рахунок } \\
\text { впровадження / } \\
\text { посилення міжнародного } \\
\text { компонента як їх } \\
\text { складової частини }\end{array}$ & студентів за обміном. \\
\hline $\begin{array}{c}\text { 3АВДАНнЯ IV. } \\
\text { Забезпечення } \\
\text { глобального виміру } \\
\text { наукових досліджень, } \\
\text { трансферу знань і } \\
\text { технологій }\end{array}$ & $\begin{array}{l}\text { 4.1. Міжнародне визнання наукових досліджень через спільні } \\
\text { iз закордонними партнерами публікації та проєкти, роботу } \\
\text { іноземних науковців у дослідницьких колективах закладу } \\
\text { вищої освіти. }\end{array}$ \\
\hline $\begin{array}{c}\text { ЗАВДАНня V. } \\
\text { Підтримка міжнародних } \\
\text { обмінів (академічна } \\
\text { мобільність) } \\
\text { співробітниками і } \\
\text { студентами }\end{array}$ & $\begin{array}{l}\text { 5.1. Робота іноземних викладачів і науковців в закладі вищої } \\
\text { освіти в рамках освітніх програм та дослідницьких проєктів } \\
\text { місцевого, національного та міжнародного рівня. } \\
\text { 5.2. Наявність іноземних студентів з університетів-партнерів } \\
\text { за різноманітними формами академічної мобільності. }\end{array}$ \\
\hline $\begin{array}{c}\text { 3АВДАННЯ VI. } \\
\text { Інтенсифікація } \\
\text { міжнародної грантової } \\
\text { діяльності та } \\
\text { фандрайзингу }\end{array}$ & $\begin{array}{l}\text { 6.1. Активізація участі в конкурсних грантових проєктах. } \\
\text { 6.2. Вагома доля міжнародної діяльності у загальному обсязі } \\
\text { надходжень університету. } \\
\text { 6.3. Сприяння участі усіх структурних підрозділів закладу } \\
\text { вищої освіти у міжнародній грантовій діяльності. }\end{array}$ \\
\hline $\begin{array}{c}\text { ЗАВДАННЯ VII. } \\
\text { Сприяння у формуванні } \\
\text { міжнародно визнаного } \\
\text { бренду університету }\end{array}$ & $\begin{array}{l}\text { 7.1. Різноплановий сучасний інформаційний матеріал } \\
\text { іноземними мовами щодо напрямів наукової, освітньої та } \\
\text { інших видів діяльності інститутів/факультетів/кафедр. } \\
\text { 7.2. Система заходів щодо просування найкращих практик } \\
\text { реалізації освітніх програм, здійснення наукових досліджень } \\
\text { тощо. } \\
\text { 7.3. Удосконалений повний набір складових іміджу/бренду } \\
\text { університету (лого, гасло, візія, місія тощо) іноземними } \\
\text { мовами; розгалужена мережа сучасних власних промоційних } \\
\text { ресурсів; представлення університету на визнаних зовнішніх } \\
\text { інформаційних ресурсах та заходах. }\end{array}$ \\
\hline $\begin{array}{l}\text { ЗАВДАННЯ VIII. } \\
\text { Інтернаціоналізація } \\
\text { вдома }\end{array}$ & 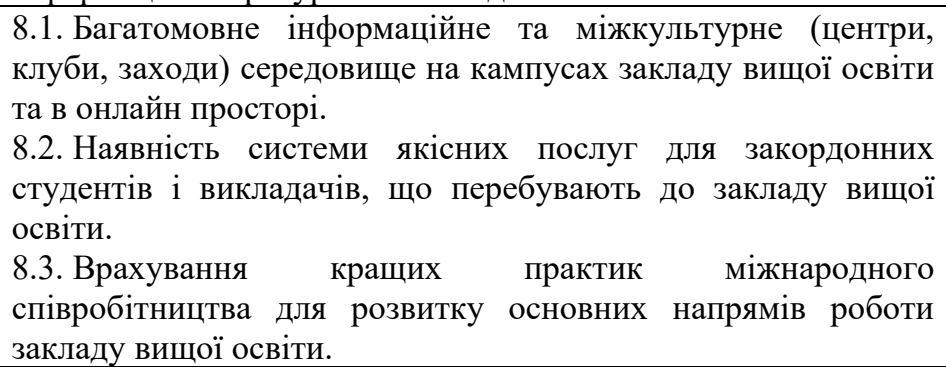 \\
\hline $\begin{array}{c}\text { ЗАВДАННЯ IX. } \\
\text { Розбудова та підтримка } \\
\text { мережі зовнішніх } \\
\text { стейкхолдерів } \\
\end{array}$ & $\begin{array}{l}\text { 9.1. Функціонування баз іноземних випускників та } \\
\text { закордонних стейкхолдерів закладу вищої освіти, наявність } \\
\text { постійного контактування, реальних заходів та спільних } \\
\text { проектів. }\end{array}$ \\
\hline
\end{tabular}

Участь у програмах мобільності студентів визначаємо в якості важливого елементу інтернаціоналізованої вищої освіти XXI століття, який має чітко окреслені наслідки для подальшої промоції професійної кар'єри випускників національних закладів вищої освіти. Ті, хто 


\section{Вісник ЛНУ імені Тараса Шевченка № 6 (344), Ч. І, 2021}

навчалися за кордоном, зазвичай демонструють вищий рівень задоволення своїм навчальним закладом, докладають більше зусиль у навчанні, ніж «немобільні» студенти (Вірс-Йенссен, 2003: 391-412); такі випускники $є$ також більш конкурентоспроможними на національному ринку праці, мають більшу ймовірність знайти престижну та високооплачувану роботу (Вірс-Йенссен, 2005: 681-705). Мобільність студентів називаємо також одним із джерел суспільних та освітніх трансформацій, на підтвердження чого свідчать кейси університетів Східної Азії та вагомість глобальної компетентності для працівників та роботодавців (Олексієнко, 2013: 1079-1101). При дослідженні мобільності як форми інтернаціоналізації системи вищої освіти інституційного рівня визначаємо низку чинників, які перешкоджають та, навпаки, стимулюють студентів до участі в програмах мобільності. Серед перших називаємо фінансові проблеми, низьку особисту мотивацію, слабку обізнаність студентів щодо умов програм мобільності, несумісність між системами вищої освіти, брак інформації про можливості мобільності, слабке знання іноземних мов, брак часу для міжнародного досвіду в рамках обраної освітньої програми, стурбованість якістю щодо досвіду, отриманого в процесі участі в програмах мобільності, правові бар'єри, зокрема щодо питань візової підтримки, проблеми з визнанням академічних досягнень за кордоном. Серед чинників, які впливають на бажання студентів узяти участь у програмах мобільності, називаємо: очевидні фінансові переваги, позитивний імідж тих, хто має досвід навчання / стажування за кордоном, відсутність мовного бар'єра, особисті міркування (наприклад, відсутність стосунків удома, планування подальшого престижного працевлаштування тощо) (Воссенстеун, 2010). Доречним у цьому контексті вважаємо такий висновок - міжнародна академічна мобільність $\epsilon$ чинником формування в студентів, викладачів та адміністративного персоналу освітніх установ низки компетентностей, необхідних для ефективного функціювання та здійснення професійної діяльності в умовах глобалізованого та турбулентного світу XXI століття; водночас мобільність сприяє розвитку культурно компетентного ставлення до світу, відповідно до якого люди постійно отримують нові знання та набувають нових умінь, вибудовуючи нові відносини 3 навколишнім середовищем. Теоретичні викладки розвідки отримали практичне підтвердження завдяки аналітичному огляду статистичних даних, представлених на офіційному електронному ресурсі UNESCO та аналітичного центру CEDOS, Україна (Мигович, 2020).

\section{Список використаної літератури}

1. Андрущенко В., Молодиченко В. Академічна мобільність: проблема реалізації в Україні і в світі. Вищза освіта України. 2010. № 1. С. 34-42. 2. Болонський процес у фактах і документах (СорбоннаБолонья-Саламанка-Прага-Берлін) / [упоряд. М. Ф. Степко, 


\section{Вісник ЛНУ імені Тараса Шевченка № 6 (344), Ч. I, 2021}

Я. Я. Болюбаш， В. Д. Шинкарук та ін.]. Тернопіль : Вид-во ТДПУ ім. В. Гнатюка, 2003. 52 с. 3. Гулясва Н. М. Мобільність викладачів і студентів: проблеми та орієнтири. Розбудова менеджмент-освіти в Україні: матеріали VI щоріч. міжнарод. конф. (м. Дніпропетровськ, 1719 лют. 2005 р.). К. : Навч.-метод. центр „Консорціум із удосконалення менеджмент-освіти в Україні", 2005. С. 76-81. 4. Журавський В. С., Згуровський М. 3. Болонський процес: головні принципи входження в Європейський простір вищої освіти. К. : Політехніка, 2003. 200 с. 5. Міністерство освіти і науки України. [Електронний ресурс]. Режим доступу : https://mon.gov.ua/ua. Назва 3 екрана. 6. Мигович I. В. Інтернаціоналізація як фактор впливу щодо трансформації систем вищої освіти країн Східної Свропи. Вісник Луганського національного університету імені Тараса Шевченка. Педагогічні науки. 2017. № 8 (313). Ч. I. C. 179-186. 7. Мигович I. В. Internationalization Process as a Way to Ensure Quality of Higher Education in Ukraine. Education and Pedagogical Sciences. 2018. № 1 (168). $\quad$ С. 17-25. $\quad$ 8. Мигович I. В. Процес інтернаціоналізації та його вплив на трансформацію національних систем вищої освіти країн Східної Свропи кінця XX - початку XXI століття : монографія. Лисичанськ : ТОВ «ФОКСПРИНТ», 2020. 628 с. 9. Мокій А. І., Лапшина I. А. Академічна мобільність: виклики і загрози для людського капіталу України. Міжнародні економічні відносини. 2009. № 11. С. 14-17. 10. Паспорт мобільності та акредитації. [Електронний ресурс]. Всеукраїнська академічна спілка, 2015. Режим доступу : $\quad$ http://aunion.info/uk/pasportmob\%D1\%96lnost\%D1\%96taakreditats\%D1\%96ya. Назва з екрана. 11. Подольская Е. А. Критерии и барьеры академической мобильности: украинский вариант. Академічна мобільність - важливий чинник освітньої євроінтеграції Украӥни : матеріали Міжнарод. наук.-практич. конф. (м. Харків, 16-19 листоп. 2010 р.). Харків: НУА, 2010. С. 267-274. 12. Шеренговський Д. В. Європейські та національні підходи до самооцінки якості міжнародної академічної мобільності. Міжнародний науковий вісник / ред. кол. : I. В. Артьомов (голова), О. І. Свєженцева, І. А. Грабова та ін. Ужгород : ДВНЗ „УжНУ”, 2015. Спецвип. 1 (10). С. 212-227. 13. Altbach Ph. G. The Perils of Internationalizing Higher Education: An Asian Perspective. International Higher Education. CIHE. 1999. № 2.34 p. 14. Altbach Ph. G., Knight J. The Internationalization of Higher Education: Motivations and Realities. Journal of Studies in International Education. 2007. Vol. 11. № 3/4. P. 290-305. 15. Amit V. Student Mobility and Internationalization: Rationales, Rhetoric, and 'Institutional Isomorphism'. Anthropology in Action. 2010. № 17 (1). P. 6-18. 16. Lenzen D. The European University in a Global Context: Internationalisation as Both a Strategic Objective and a Response to Global Developments. Report at the EUA 2009 Autumn Conference. Internationalisation beyond Europe's Frontiers: Enhancing Attractiveness through Global Partnership and Cooperation. Mode of access : http://www.eua.be/events/autumn-conference-2009/presentations/\#c2907. 


\section{Вісник ЛНУ імені Тараса Шевченка № 6 (344), Ч. I, 2021}

Title from screen. 17. Mobility for Better Learning: Mobility strategy 2020 for the European Higher Education Area (EHEA). [Electronic Source]. European Higher Education Area Ministerial Conference. Bucharest, 2012. p. 4. Mode of access : http://www.ehea.info/Uploads/(1)/2012\%20EHEA\%20Mobility\% 20Strategy.pdf. Title from screen. 18. Oleksiyenko A., Cheng, K., Yip, H. International Student Mobility in Hong Kong: Private Good, Public Good, or Trade in Services? Studies in Higher Education. 2013. № 38 (7). P. 10791101. 19. Teichler U. Internationalisation of Higher Education: European Experiences. Asia Pacific Education Review. 2009. Vol. 10 (1). P. 93-106. 20. The Bologna Process 2020: The European Higher Education Area in the New Decade. Communique of the Conference of European Ministers Responsible for Higher Education. Leuven and Leuven-la-Neuve. Mode of access : http://europa.eu/rapid/press-release_IP-09-675_en.htm. Title from screen. 21. Torfi J. J. Inventing Tomorrow's University. Who is to Take the Lead? Bologna University Press, 2008. 160 p. 22. Vossensteyn H., Beerkens M., Cremonini L. Improving the Participation in the ERASMUS Programme. Brussels : European Parliament, 2010. 187 p. 23. WiersJenssen J. Norwegian Students Abroad: Experiences of Students from a Linguistically and Geographically Peripheral European Country. Studies in Higher Education. 2003. Vol. 28. P. 391-412. 24. Wiers-Jenssen J., Try S. Labour Market Outcomes of Higher Education Undertaken Abroad. Studies in Higher Education. 2005. Vol. 30. P. 681-705.

\section{References}

1. Andrushchenko, V., \& Molodychenko, V. (2010). Akademichna mobilnist: problema realizatsii $\mathrm{v}$ Ukraini i v sviti [Academic mobility: the problem of implementation in Ukraine and in the world]. Vyshcha osvita Ukrainy - Higher education in Ukraine, 1, 34-42 [in Ukrainian]. 2. Stepko, M. F., Boliubash, Ya. Ya., \& Shynkaruk, V. D. et al. (Eds.). (2003). Bolonskyi protses u faktakh i dokumentakh (Sorbonna-BoloniaSalamanka-Praha-Berlin) [Bologna process in facts and documents (SorbonneBologna-Salamanca-Prague-Berlin)]. Ternopil: Vyd-vo TDPU im. V. Hnatiuka [in Ukrainian]. 3. Huliaieva, N. M. (2005). Mobilnist vykladachiv i studentiv: problemy ta oriientyry [Mobility of teachers and students: problems and guidelines]. Rozbudova menedzhment-osvity $v$ Ukraini - Development of management education in Ukraine. (pp. 76-81). K.: Navch.-metod. tsentr ,Konsortsium iz udoskonalennia menedzhment-osvity v Ukraini” [in Ukrainian]. 4. Zhuravskyi, V. S., \& Zghurovskyi, M. Z. (2003). Bolonskyi protses: holovni pryntsypy vkhodzhennia v Yevropeiskyi prostir vyshchoi osvity [The Bologna Process: the main principles of entering the European Higher Education Area]. Kyiv: Politekhnika [in Ukrainian]. 5. Ministerstvo osvity i nauky Ukrainy [Ministry of Education and Science of Ukraine]. (2021). Retrieved from https://mon.gov.ua/ua [in Ukrainian]. 6. Myhovych, I. V. (2017). Internatsionalizatsiia yak faktor vplyvu shchodo transformatsii system vyshchoi osvity krain Skhidnoi Yevropy 


\section{Вісник ЛНУ імені Тараса Шевченка № 6 (344), Ч. I, 2021}

[Internationalization as a factor influencing the transformation of higher education systems in Eastern Europe]. Visnyk Luhanskoho natsionalnoho universytetu imeni Tarasa Shevchenka. Pedahohichni nauky - Bulletin of Luhansk Taras Shevchenko National University. Pedagogical sciences, 8 (313), I, 179-186 [in Ukrainian]. 7. Myhovych, I. V. (2018). Internationalization Process as a Way to Ensure Quality of Higher Education in Ukraine. Education and Pedagogical Sciences, 1 (168), 17-25 [in English]. 8. Myhovych, I. V. (2020). Protses internatsionalizatsii ta yoho vplyv na transformatsiiu natsionalnykh system vyshchoi osvity krain Skhidnoi Yevropy kintsia XX - pochatku XXI stolittia [The process of internationalization and its impact on the transformation of national higher education systems in Eastern Europe in the late XX - early XXI century]. Lysychansk: TOV „FOKSPRYNT” [in Ukrainian]. 9. Mokii, A. I., \& Lapshyna, I. A. (2009). Akademichna mobilnist: vyklyky i zahrozy dlia liudskoho kapitalu Ukrainy [Academic mobility: challenges and threats to Ukraine's human capital]. Mizhnarodni ekonomichni vidnosyny - International Economic Relations, 11, 14-17 [in Ukrainian]. 10. Pasport mobilnosti ta akredytatsii [Mobility and accreditation passport]. (2015). Vseukrainska akademichna spilka. Retrieved from http://aunion.info/uk/pasportmob\%D1\%96lnost\%D1\%96taakreditats\%D1\%96ya [in Ukrainian]. 11. Podolskaia, E. A. (2010). Kryteryy i bariry akademycheskoi mobylnosty: ukraynskyi varyant [Criteria and barriers to academic mobility: Ukrainian version]. Akademichna mobilnist-vazhlyvyi chynnyk osvitnoi yevrointehratsii Ukrainy - Academic mobility is an important factor in Ukraine's educational European integration. (pp. 267-274). Kharkiv: NUA [in Russian]. 12. Sherenhovskyi, D. V. (2015). Yevropeiski ta natsionalni pidkhody do samootsinky yakosti mizhnarodnoi akademichnoi mobilnosti [European and national approaches to selfassessment of the quality of international academic mobility]. Mizhnarodnyi naukovyi visnyk - International Scientific Bulletin, 1 (10), 212-227. Uzhhorod: DVNZ „UzhNU” [in Ukrainian]. 13. Altbach, Ph. G. (1999). The Perils of Internationalizing Higher Education: An Asian Perspective. International Higher Education. CIHE, 2 [in English]. 14. Altbach, Ph. G., \& Knight, J. (2007). The Internationalization of Higher Education: Motivations and Realities. Journal of Studies in International Education, 11, 3/4, 290-305 [in English]. 15. Amit, V. (2010). Student Mobility and Internationalization: Rationales, Rhetoric, and 'Institutional Isomorphism'. Anthropology in Action, 17 (1), 6-18 [in English]. 16. Lenzen, D. (2009). The European University in a Global Context: Internationalisation as Both a Strategic Objective and a Response to Global Developments. Report at the EUA 2009 Autumn Conference. Internationalisation beyond Europe's Frontiers: Enhancing Attractiveness through Global Partnership and Cooperation. Retrieved from http://www.eua.be/events/autumn-conference-2009/presentations/\#c2907 [in English]. 17. Mobility for Better Learning: Mobility strategy 2020 for the European Higher Education Area (EHEA). (2012). European Higher Education Area Ministerial Conference. (p. 4). Bucharest. Retrieved from 


\section{Вісник ЛНУ імені Тараса Шевченка № 6 (344), Ч. I, 2021}

http://www.ehea.info/Uploads/(1)/2012\%20EHEA\%20Mobility\%20Strategy. pdf [in English]. 18. Oleksiyenko, A., Cheng, K., \& Yip, H. (2013). International Student Mobility in Hong Kong: Private Good, Public Good, or Trade in Services? Studies in Higher Education, 38 (7), 1079-1101 [in English]. 19. Teichler, U. (2009). Internationalisation of Higher Education: European Experiences. Asia Pacific Education Review, 10 (1), 93-106 [in English]. 20. The Bologna Process 2020: The European Higher Education Area in the New Decade. (2020). Communique of the Conference of European Ministers Responsible for Higher Education. Leuven and Leuven-la-Neuve. Retrieved from http://europa.eu/rapid/press-release_IP-09-675_en.htm [in English]. 21. Torfi, J. J. (2008). Inventing Tomorrow's University. Who is to Take the Lead? Bologna University Press [in English]. 22. Vossensteyn, H., Beerkens, M., \& Cremonini, L. (2010). Improving the Participation in the ERASMUS Programme. Brussels: European Parliament [in English]. 23. Wiers-Jenssen, J. (2003). Norwegian Students Abroad: Experiences of Students from a Linguistically and Geographically Peripheral European Country. Studies in Higher Education, 28, 391-412 [in English]. 24. WiersJenssen, J., \& Try, S. (2005). Labour Market Outcomes of Higher Education Undertaken Abroad. Studies in Higher Education, 30, 681-705 [in English].

Мигович I. В. Стандарти якості академічної мобільності як елемента системи вищої освіти кінця XX - початку XXI століття та як форми іїі інтернаціоналізації

Представлена теоретико-методологічна розвідка має на меті схарактеризувати особливості процесу академічної мобільності як невід'ємного елемента міжнародного освітнього ландшафта кінця XX початку XXI століття та водночас як однієї із форм національних політик інтернаціоналізації систем вищої освіти країн світу, яка покликана сприяти інтенсивному розвитку компетентностей іiі учасників, необхідних для здійснення ефективної професійної діяльності в глобалізованому світі кінця XX - початку XXI століття; забезпеченню якості освітніх послуг, що їх надають національні заклади вищої освіти; забезпеченню інноваційності та привабливості для потенційних студентів (у тому числі і іноземних громадян) національної вищої освіти, що, в свою чергу, посилює конкурентоспроможність національних освітніх інституцій. Здійснений в роботі аспектний аналіз названих процесів дозволяє твердити, що інтернаціоналізація національних систем вищої освіти передбачає будь-яку діяльність в межах функціювання системи (чи закладу) вищої освіти, що здійснюється із залученням закордонного (міжкультурного) досвіду, в якій задіяні всі суб'єкти освітнього процесу; при цьому міжнародна академічна мобільність передбачає наявність можливості упродовж періоду навчання вчитися один або більше семестрів у закладі вищої освіти іншої країни 3 зарахуванням дисциплін (кредитів) та періоду навчання. Враховуючи вищезазначене, істотної ваги набуває вивчення наявних європейських та 


\section{Вісник ЛНУ імені Тараса Шевченка № 6 (344), Ч. І, 2021}

світових стандартів якості академічної мобільності, розроблених та впроваджених з метою забезпечення ефективної реалізації національних політик інтернаціоналізації країн світу.

Ключові слова: міжнародна академічна мобільність, стандарти якості, Свропейський простір вищої освіти (досліджень), глобалізація, інтернаціоналізація.

Мигович И. В. Стандарты качества академической мобильности как элемента системы высшего образования конца XX - начала XXI века и как формы ее интернационализации

Представленное теоретико-методологическое исследование имеет своей целью охарактеризовать особенности процесса академической мобильности как неотъемлемого элемента международного образовательного ландшафта конца XX - начала XXI века и одновременно как одной из форм национальной политики интернационализации систем высшего образования стран мира, которая призвана способствовать интенсивному развитию компетентностей ее участников, необходимых для осуществления эффективной профессиональной деятельности в глобализированном мире конца XX начала XXI века; обеспечению качества образовательных услуг, предоставляемых национальными высшими учебными заведениями; обеспечению инновационности и привлекательности для потенциальных студентов (в том числе и иностранных граждан) национального высшего образования, что, в свою очередь, усиливает конкурентоспособность национальных образовательных учреждений. Проведенный в работе аспектный анализ названных процессов позволяет утверждать, что интернационализация национальных систем высшего образования предусматривает любую деятельность в пределах функционирования системы (или учреждения) высшего образования, осуществляемую с привлечением зарубежного (межкультурного) опыта, в которой задействованы все субъекты образовательного процесса; при этом международная академическая мобильность предполагает наличие возможности в течение периода обучения учиться один или более семестров в заведении высшего образования другой страны с зачислением дисциплин (кредитов) и периода обучения. Учитывая вышесказанное, существенное значение приобретает изучение имеющихся европейских и мировых стандартов качества академической мобильности, разработанных и внедренных в целях обеспечения эффективной реализации национальных политик интернационализации стран мира.

Ключевые слова: международная академическая мобильность, стандарты качества, Европейское пространство высшего образования (исследований), глобализация, интернационализация. 


\section{Вісник ЛНУ імені Тараса Шевченка № 6 (344), Ч. I, 2021}

Myhovych I. Quality Standards of Academic Mobility as an Element of Higher Education System of the late XX - early XXI century and as a Form of its Internationalization

The article presents theoretically-methodological research conducted to characterize the process of academic mobility as an integral part of international educational landscape of the late XX - early XXI century, and at the same time as one of the forms of national policies of internationalization of higher education, which is in considerable demand when it comes to realization of effective professional activity in the globalized world of the late XX - early XXI century. This form ensures quality of educational services provided by national higher education institutions, ensures innovative character and attractiveness of national higher education for potential students (including foreign citizens). All this, in turn, strengthens the competitiveness of national educational institutions. The aspectual analysis of the mentioned processes allows to state that internationalization of national higher education involves any activity within the system (or institution) of higher education carried out with the involvement of foreign (intercultural) experience, which touches upon all subjects of educational process. International academic mobility provides for the possibility during the period of study to study one or more semesters in a higher education institution of another country, including disciplines (credits) and the period of study. Given the above, it is important to study the existing European and world standards of quality of academic mobility, developed and implemented to ensure the effective implementation of national policies of internationalization.

Key words: International Academic Mobility, Quality Standards, European Higher Education (Research) Area, Globalization, Internationalization.

Стаття надійшла до редакції 13.09.2021 р. Прийнято до друку 24.09.2021 p. Рецензент - д. П. н., проф. Курило В. С. 